\title{
Entrelacs
}

Cinéma et audiovisuel

HS | 2012

Le post-humain et les enjeux du sujet

\section{Envisager Orlan, corps et identités dans le monde contemporain}

\section{Angélique Gozlan}

\section{(2) OpenEdition}

\section{Journals}

Édition électronique

URL : http://journals.openedition.org/entrelacs/304

DOI : 10.4000/entrelacs.304

ISSN : 2261-5482

Éditeur

Éditions Téraèdre

\section{Édition imprimée}

Date de publication : 2 février 2012

ISBN : 978-2296567177

ISSN : 1266-7188

\section{Référence électronique}

Angélique Gozlan, «Envisager Orlan, corps et identités dans le monde contemporain », Entrelacs [En ligne], HS | 2012, mis en ligne le 01 août 2012, consulté le 22 avril 2019. URL : http:// journals.openedition.org/entrelacs/304 ; DOI : 10.4000/entrelacs.304

Ce document a été généré automatiquement le 22 avril 2019

Tous droits réservés 


\title{
Envisager Orlan, corps et identités dans le monde contemporain
}

\author{
Angélique Gozlan
}

« Nous sommes à la charnière d'un monde pour lequel nous ne sommes pas prêts, ni physiquement ni intellectuellement. (...) Dès qu'il y a des avancées, qu'elles soient technologiques, scientifiques, ou biotechnologiques, elles font peur

et provoquent des réactions épidermiques de résistance, d'opposition et de retour à la tradition, à l'ordre. (...) Il est nécessaire que certains artistes essaient de se préparer et de préparer le public à ces grands changements qui sont en train de se produire. »

B. Hatat. « Entretien avec Orlan », L'en-je lacanien, 2004/2, n³, p.179. ORLAN.

1 Le texte complet de cet article est publié dans l'ouvrage :

Post humain et les enjeux du sujet

Editeur : L'HARMATTAN (2 février 2012)

Collection Ouverture Philosophique

ISBN-10 : 2296567177

ISBN-13 : 978-2296567177 


\section{RÉSUMÉS}

Dans le contexte actuel d'une société en plein remaniement technologique et médical, ORLAN, artiste de renommée internationale, touche à l'essence même de l'être humain : l'image, le corps, l'identité et ses limites. En nous appuyant sur son œuvre, précurseur des questions sur le posthumain, nous interrogerons les notions de corps et d'identités de nos jours. ORLAN révèle une crise du corps contemporain, un corps qui se cherche, oscillant entre dépossession et réappropriation, ouvrant la voie à la mise en acte d'un imaginaire individuel et collectif. L'issue de cette crise semble être la réalisation d'un corps-image, corps mixte et narcissique. Avec ses self-hybridations, ORLAN induit une nouvelle ère : la réalisation de l'homme via l'écran-miroir du numérique.

\section{AUTEUR}

\section{ANGÉLIQUE GOZLAN}

Psychologue clinicienne, doctorante en psychopathologie et psychanalyse, Paris VII. 